\title{
Influences of landscape structure on butterfly diversity in urban private gardens using a citizen science approach
}

\author{
Manfred Pendl $^{1} \cdot$ Raja Imran Hussain ${ }^{1}$ (D) Dietmar Moser $^{2} \cdot$ Thomas Frank $^{1} \cdot$ Thomas Drapela $^{3}$
}

Accepted: 21 September 2021 / Published online: 25 September 2021

(c) The Author(s) 2021

\begin{abstract}
Although urbanization is increasing worldwide, private gardens may help mitigate the impact of urbanization on butterfly diversity. We investigated how local and landscape factors correspond with the observed butterfly species diversity and species composition in Viennese private gardens. The goal is to determine the importance of private gardens for butterfly conservation. Butterfly species were observed by skilled volunteers by applying a citizen science approach. We related butterfly species numbers in private gardens with local parameters and landscape composition in a radius of $1 \mathrm{~km}$ around each garden. Data were analyzed using a regression approach based on generalized linear models. The butterfly species richness in private gardens was positively correlated with butterfly species richness in the surrounding landscapes. Butterfly species richness in private gardens increased with higher proportions of area relevant for butterflies in the surrounding landscape and with increasing numbers of host and nectar plant species in the private gardens. A higher proportion of wooded areas in the surrounding landscape was related with a smaller proportion of the landscape butterfly species pool being observed in the private gardens. Overall, our results could be useful in land use planning, and for future studies of how to integrate citizen science and make urban gardens more beneficial for butterfly conservation.
\end{abstract}

Keywords Butterflies $\cdot$ Citizen science $\cdot$ Private gardens $\cdot$ Lepidoptera $\cdot$ Urban biodiversity $\cdot$ Landscape

\section{Introduction}

Urbanization is expanding worldwide (Carlucci et al. 2020), resulting in habitat modifications (Liu et al. 2016) which often alter the composition and distribution of species (Freitas et al. 2020), including insects (Corcos et al. 2019). Specifically, native invertebrate diversity mostly decreases with increasing urbanization, especially in central urban

Manfred Pendl and Raja Imran Hussain contributed equally to the work

Raja Imran Hussain

raja.hussain@boku.ac.at

1 Department of Integrative Biology and Biodiversity Research, Institute of Zoology, University of Natural Resources and Life Sciences, Gregor Mendel-Strasse 33, 1180 Vienna, Austria

2 Division of Conservation Biology, Vegetation Ecology and Landscape Ecology, Faculty Centre of Biodiversity, University of Vienna, Rennweg 14, 1030 Vienna, Austria

3 Research Institute of Organic Agriculture (FiBL), Doblhoffgasse 7/10, 1010 Vienna, Austria core areas (Matteson and Langellotto 2010; Kuussaari et al. 2021). Furthermore, urbanization is a significant factor in both current and predicted species declines (Lee et al. 2015) and has been estimated to reduce butterfly diversity by $85 \%$ (Piano et al. 2020). Nonetheless, urban areas still accommodate species in semi-natural habitat remnants as well as in human-made habitats like private gardens. In recent years, ecologists have shown growing interest in the role and significance of private gardens for urban biodiversity (O'Connell et al. 2021).

Recent research has put urban biodiversity into the conservation focus, either by examining multi-city analyses at larger scales (Baldock et al. 2019; Cubino et al. 2020) or by focusing on patches within the urban landscape (Jain et al. 2020). The latter include semi-natural grassland (Öckinger et al. 2009), high-value urban green areas (Dylewski et al. 2019), green roofs (MacIvor and Lundholm 2011), community gardens (Matteson and Langellotto 2010), private gardens (Fontaine et al. 2016), and fallows or brownfields (Woodward et al. 2003). Most of the biodiversity monitoring studies have been undertaken at several scales of investigation, i.e. from a single garden to different land-uses and 
management practices, to predict the biodiversity response to urbanization (Lerman et al. 2018; Cubino et al. 2020). However, such biodiversity research, including studies on insects, has so far been conducted without conservationbased citizen science approaches.

Citizen science approaches are flourishing around the world, particularly as a means of biodiversity assessment at a large scale (Pocock et al. 2017). Much of the recent upsurge in citizen science has involved mass-participation projects, which seek to engage people with little or no previous experience in biodiversity monitoring (Loos et al. 2015). Such monitoring programs have the potential to play an even larger role in conservation by educating and encouraging participants to engage in conservation activities (Lewandowski and Oberhauser 2016). As urbaniziation increases (Pickett et al. 2011), there is growing recognition of the benefits of monitoring and conserving insect biodiversity in and around cities (Sanderson and Huron 2011). In light of butterfly biodiversity decline (Warren et al. 2021), citizen science will be an important approach to monitor butterfly biodiversity in urban landscapes (Baker and Potter 2019).

Butterflies are among the most charismatic and popular insect groups, and many people associate positive feelings with them because of their spectacular, colorful wings and their image as indicators for natural habitats (Kühn et al. 2008; Han et al. 2021), however they are declining dramatically (Hallmann et al. 2017; Warren et al. 2021). The major cause of this decline is loss of appropriate habitats due to land-use changes such as agricultural intensification and urbanization. Nevertheless, urban landscapes can harbor diverse populations of butterflies, not just rare and endangered species (Strausz et al. 2012). Studies recommend considering landscape configuration for butterfly conservation and management because butterfly communities are composed of species with different habitat requirements (Liivamägi et al. 2014) and the quality of the environment (Lizée et al. 2011). In urban landscapes, high-quality grasslands (Dylewski et al. 2019) and flowering nectar plants (Han et al. 2021) can support rich and abundant butterfly populations.

The urban landscape is interspersed with fragmented and heavily managed gardens, woody areas, grassland, parks, greenways and other green spaces, which facilitate movement of butterflies and increase local species richness (Matteson and Langellotto 2010). Some publications encourage the public to make private gardens more butterfly-friendly by increasing the number of flowering nectar plants and host plants (e.g. Goddard et al. 2013; Fontaine et al. 2016). Restricted access to private gardens and the difficulty of biodiversity data collection in urban habitats probably accounts for the paucity of research on this topic but several studies have revealed that private garden characteristics are an important determinant for butterfly diversity (Vickery 2007; Majewska et al. 2018), whereas others have concluded that the surrounding landscape plays the key role (Steffan-Dewenter and Tscharntke 2000; Dover and Settele 2009). Of the surrounding landscape types, semi-natural grassland and woodland are influential for butterfly dispersal (Bergerot et al. 2012; Bergman et al. 2018). Furthermore, understanding butterfly and plant distribution is a pre-requisite for developing conservation strategies, particularly for urban ecosystems (Mukherjee et al. 2018). Therefore, we tested whether species richness and relative species richness in private gardens in Vienna were correlated with parameters of landscape composition (proportion of woody areas, grassland, and gardens, respectively), with species richness in the landscape species pool, and/or with private garden characteristics (diversity of nectar and host plant species, respectively).

\section{Materials and methods}

\section{Study sites}

Vienna is situated in the northeast of Austria at the Danube River, between the foothills of the Alps and the Carpathians at altitudes between 151 and $543 \mathrm{~m}$ above sea level. To the west and to the north, the city is surrounded by an extensively managed cultivated landscape (Vienna Woods/Wienerwald) with many semi-natural, herb-rich meadows and deciduous forests. The landscape east and south of the city is characterized by intensive agriculture. To the southeast lies the Viennese part of the Donau-Auen National Park with a mosaic of alluvial forests, wet and dry grasslands. The climate is humid continental with an average temperature (30-year average) of $11.4{ }^{\circ} \mathrm{C}$ in the city center and $10.2{ }^{\circ} \mathrm{C}$ in suburban areas; mean annual precipitation ranges from more than $700 \mathrm{~mm}$ in the west to less than $550 \mathrm{~mm}$ in the east and southeast (Central Institute for Meteorology and Geodynamics 2016). Green areas (parks, agricultural areas, forests, gardens) make up around half of Vienna's surface area. The proportion of green areas within the individual municipal districts varies from two to 15 percent in the inner-city regions up to 70 percent in the Vienna outskirts (Municipal Department 22Environmental Protection). We included 21 private gardens, distributed across Vienna, in our study design (Fig. 1). We built a network of volunteers with the help of targeted media (newspaper reports, TV and radio), talks and information booths at various (garden) events. The focus was on attracting many participants for the butterfly count and keeping the barrier to participation as low as possible. Subsequently, a central communication point comprising participants and experts was established for the monitoring and to train participants before butterfly observation. 


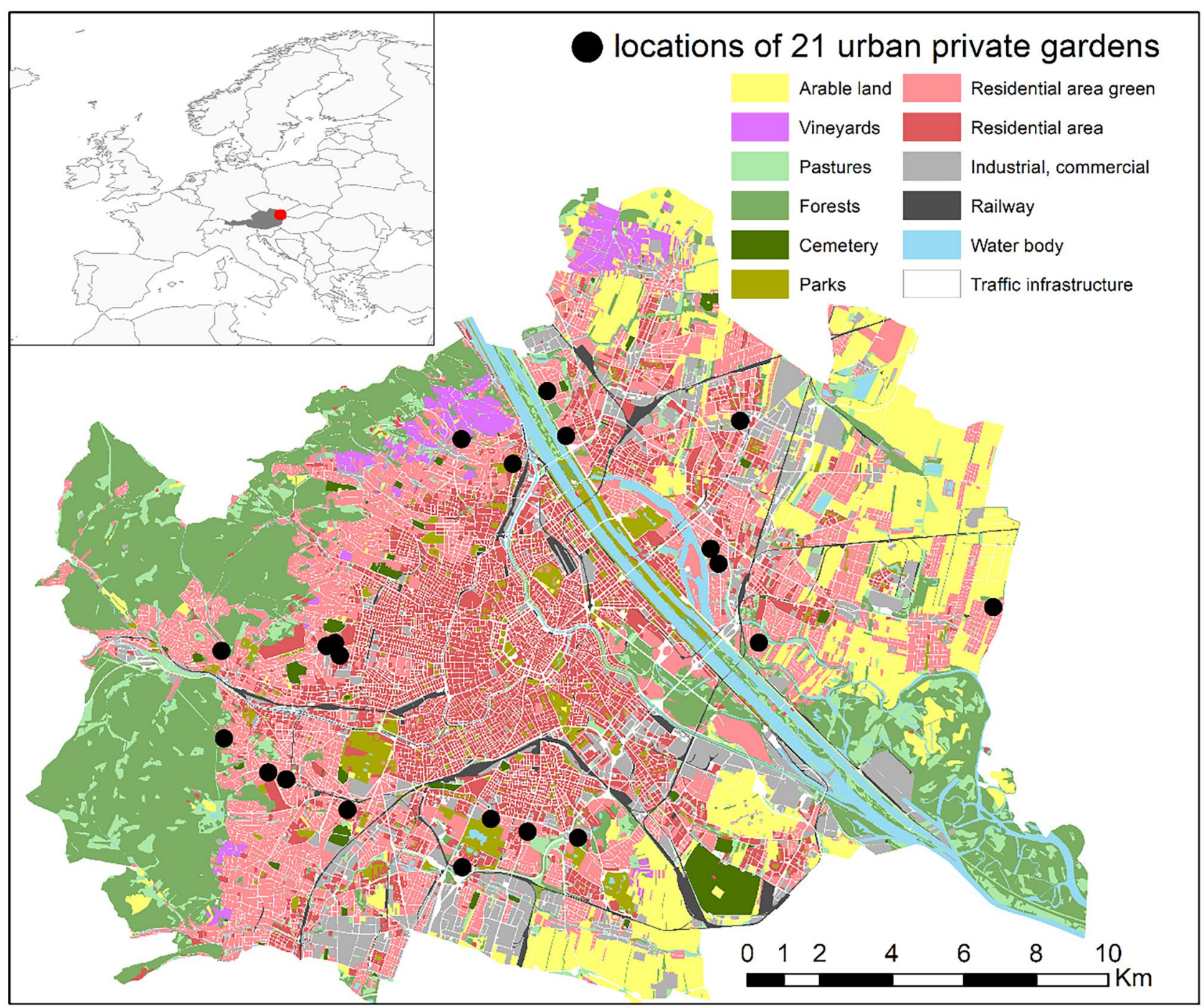

Fig. 1 Map of the locations (black circles) of 21 urban private gardens in Vienna, Austria. The map was created in ArcGIS (source: Bivand et al. 2019; Land use of Vienna: Realnutzungskartierung 2018)

\section{Butterfly observation and data collection}

We used data collected by trained volunteers in 21 private gardens in the "Vienna butterfly census", a Citizen Science project which took place in 2005 . We formulated criteria for private garden selection to ensure data quality: participation in the project for at least one year, species knowledge estimated by the proportion of unidentified species in particpants' recorded species lists, plausibility of recorded species, and personal impression during visits to participants' private gardens. The average size of the private gardens was approx. $380 \mathrm{~m}^{2}$, and the average private garden area examined by the particpants was $124 \mathrm{~m}^{2}$. On average, 25 species of flowering plants were recorded in the private gardens. All private gardens were managed by participants themselves. The private gardens selected for observation were mainly in the western districts of Vienna, with nearby forests, meadows and vineyards along the eastern edge of the Alps. To guarantee data quality, regular communication and training was maintained with participants, and support in the form of identification sheets with species descriptions was provided. These regular communication and training improved participants skills and data reliability to identify butterflies. All gardeners were trained to count specimens using the line-transect method by Pollard and Yates (1993). However, gardeners who were classified as not capable in butterfly identification have been excluded for further analysis. Transect length was limited by recording time - five minutes per $90 \mathrm{~m}$ transect walk - and each butterfly within $5 \mathrm{~m}$ on either side and in front of the recorder was noted. Transect walks were restricted to sunny periods between $10 \mathrm{a} . \mathrm{m}$. and $3 \mathrm{p} . \mathrm{m}$. and were conducted nine times, randomly, from June to August. Species 
counts of all nine transect walks were pooled for analyses. The "Whites" (e.g., Pieris rapae, P. brassicae, P. napi and Leptidea sinapis/juvernica) were not included in the analyses because of uncertainties in species identification. We combined the Small Heath (Coenonympha pamphilus) and Chestnut Heath (C. glycerion) under Coenonympha spp., because the typical wing spots become unclear at the end of their lifespan, making them more difficult to distinguish. They use similar host plants, and their habitats can overlap, but $C$. pamphilus is more widespread in Vienna (Höttinger et al. 2013). For the data evaluation, quality and plausibility checks, participants were told to provide photo evidence. Finally, Manfred Pendl as a butterfly expert verified the collected butterfly data.

As response variables, we calculated species richness and relative species richness for each private garden. The latter is the number of butterfly species in a private garden divided by the number of butterfly species in the surrounding landscape (i.e., the landscape species pool). Data for the landscape species pool were obtained from a database comprising all distributional data for butterflies in grid cells of $1250 \mathrm{~m} \times 1000 \mathrm{~m}$ (Höttinger et al. 2006). The landscape species pool of each private garden was calculated as the total number of butterfly species in the grid cell containing the private garden and the eight adjacent grid cells. The species data in the database (Höttinger et al. 2006) were collected using the transect method at approximately the same time as the private garden observation. Species lists from these grid cells were compared with the species list from the respective private garden for plausibility. All species recorded in the private gardens also occurred in the respective landscape species pools.

\section{Garden and landscape variables}

The number of butterfly nectar plant species and number of host plant species per private garden (Settele et al. 2000) were used to describe private garden quality for butterflies (Table 1). Each plant species was recorded along the transect walk by an expert at the same time when participants started butterfly observation. The minimum level of plant identification was genus, but most were determined to species level. Only nectar plants flowering during the survey period were considered. To calculate the landscape variables, the 43 land cover categories contained in a land cover map provided by the city of Vienna (City of Vienna 2016) were reclassified to wooded areas (WOOD: included areas with the categories forest and other tree dominated areas, incl. parks if appropriate), grassland dominated areas (GRASS: included the categories grassland/meadows and fallows), gardens (GARDEN: included the category garden with house gardens, allotments and suburban residential zone), nectar plants (NECTAR: plants with flower and nectar), host plant species (HOST: plants required for butterfly growth and larval development), and area relevant for butterflies as sum of Wood and Grass (ARB) (Table 1, A-1); land cover categories that were considered not relevant for butterflies were excluded (e.g., traffic areas or densely built-up urban residential and commercial zones). Subsequently, we calculated the proportions of these landscape categories within a radius of $1 \mathrm{~km}$ around each private garden.

\section{Statistical analyses}

We first analyzed differences in total butterfly species richness and abundance between private gardens and the surrounding landscape using ANOVA. Here, total species richness was calculated as the aggregated number of butterfly species observed per site. To examine the relative strength of confounding effects between private gardens and landscape variables, we used generalized linear models $(\mathrm{glm})$ to analyze which variables contributed to explaining the observed butterfly species richness and relative species richness. Generalized linear models were calculated using the 'glm'function from the package 'rms' in R (www.r-project.org). We used the Poisson link function for species richness models, and the Gaussian link function for relative species richness models. Model selection and inference were based on
Table 1 List of explanatory variables including abbreviation, mean and range. Wooded areas ('WOOD'; included areas with the category forest and tree dominated areas), grasslands ('GRASS'; included the category grassland/meadows and fallows), gardens ('GARDEN'; included the category garden with house gardens, allotments and suburban residential zone), area relevant for butterflies ('ARB'; sum of the three other landscape variables)

\begin{tabular}{|c|c|c|c|}
\hline Explanatory Variable & Abbreviation & Mean & Range \\
\hline Proportion wooded areas at radius $1000 \mathrm{~m} \mathrm{( \% )}$ & WOOD & 10.6 & $0.5-47.2$ \\
\hline Proportion gardens at radius $1000 \mathrm{~m} \mathrm{( \% )}$ & GARDEN & 26.5 & $7.9-40.7$ \\
\hline Proportion grassland at radius $1000 \mathrm{~m} \mathrm{( \% )}$ & GRASS & 6.7 & $0.2-20.1$ \\
\hline Proportion area relevant for butterflies (\%) & $\mathrm{ARB}$ & 43.8 & $25.1-83.3$ \\
\hline Species richness landscape species pool & POOL & 31.1 & $11-80$ \\
\hline Number of nectar plant species & NECTAR & 21.6 & $6-46$ \\
\hline Number of host plant species & HOST & 4.7 & $1-15$ \\
\hline
\end{tabular}


Akaike's Information Criterion (AIC) and Akaike weights $\left(w_{i}\right)$. We used the AIC in its corrected form AICc because sample size was small (21 private gardens) relative to the number of variables. The presence of overdispersion was checked for by adding observation level as a random factor in the model (Harrison 2014; Hussain et al. 2021). We verified model assumptions (i.e. normality of model residuals and variance homogeneity) by visually inspecting residual plots. Pearson rank correlation was computed to assess the relationship between different landscape variables and species richness and abundance. To determine the abundancebased species richness estimates in each of the 21 sampled private gardens, we used the $i N E X T$ package in $\mathrm{R}$ that uses counts (numbers of individuals) of species at a single site.

\section{Results}

In total, 624 butterfly individuals comprising 12 species were recorded (Table 2). The most frequently observed species were Maniola jurtina (16 private gardens), Vanessa atalanta (14 private gardens) and Iphiclides podalirius (13 private gardens); no species was observed in all private gardens. Butterfly species richness ranged from 4 to 10 species per private garden. The landscape species pool comprised between 11 and 80 species. Relative species richness ranged from $11.3 \%$ to $53.8 \%$.

The number of observed butterfly species in private gardens increased with higher proportions of area relevant for butterflies in the surrounding landscape $\left(\mathrm{F}_{1,19}=8.78\right.$, $\mathrm{p}=0.007$; Fig. 2A), and with increasing numbers of host plant $\left(\mathrm{F}_{1,19}=2.46, \mathrm{p}<0.05\right.$; Fig. 2B $)$ and nectar plant species in the private gardens $\left(F_{1,19}=1.74, p<0.05\right.$; Fig. $\left.2 \mathrm{C}\right)$. The relation with proportion of wooded habitats was negative, i.e., the higher the proportion of wooded areas in the surrounding landscape, the smaller the proportion of the landscape species pool that was observed in the private gardens $\left(F_{1,19}=2.40, p<0.05\right.$; Fig. 2D). In contrast, the relation with the number of nectar plant species in the surrounding landscape was positive $\left(\mathrm{F}_{1,19}=0.32, \mathrm{p}<0.05\right.$; Fig. 2E). Species richness in the private gardens was positively correlated with species richness in the surrounding landscapes $(r=0.50, p=0.01$, Fig. 3). We did not find any significant effect of landscape variables on butterfly abundance in the private gardens. Maniola jurtina was more frequently recorded where the landscape species pool was more diverse and the proportion of woody habitats in the surrounding landscape was lower. Aglais urticae was positively correlated with several explanatory variables (Table 1; GRASS, GARDEN, NECTAR, HOST) but also negatively correlated with WOOD. In contrast, two other species, Issoria lathonia and Neptis rivularis, were positively related to the proportion of woody habitats in the surrounding landscape.

\section{Discussion}

Several studies have identified nectar plants as a determining factor for enhanced attractiveness of gardens for butterflies (Schneider et al. 2003; Straka 2004; Fontaine et al. 2016). Different nectar resources are attractive for adult butterfly individuals (e.g., Phengaris spp.), and promote their
Table 2 Butterfly species list from the three-month recording period in 2005 in Viennese gardens. Whites were excluded because of uncertainty in identification. The Heaths are pooled to Coenonympha spp. Raster frequency in Vienna (Höttinger et al. 2013); Mobility/dispersion ability: 1 (extremely low mobility) to 9 (migrant butterfly); Host

\begin{tabular}{|c|c|c|c|c|c|c|c|}
\hline Scientific name & Abbreviation & $\begin{array}{l}\text { Frequency } \\
\text { in gardens } \\
(\%)\end{array}$ & $\begin{array}{l}\text { Raster } \\
\text { frequency in } \\
\text { Vienna (\%) }\end{array}$ & $\begin{array}{l}\text { Mobility/ } \\
\text { dispersion } \\
\text { ability }\end{array}$ & Host plant specialization & Red list status & VCR \\
\hline Maniola jurtina & MANJUR & 76.2 & 59.4 & $4-6$ & polyphagous & - & \\
\hline Vanessa atalanta & VANATA & 66.7 & 46.9 & 9 & monophagous & - & \\
\hline Iphiclides podalirius & IPHPOD & 61.9 & 47.4 & $4-6$ & monophagous & VU & priority protected \\
\hline Inachis io & INAIO & 57.1 & 55.9 & 6 & polyphagous & - & \\
\hline Gonepteryx rhamni & GONRHA & 47.6 & 40.1 & 6 & oligophagous & - & \\
\hline Argynnis paphia & ARGPAP & 47.6 & 43.1 & 4 & monophagous & - & \\
\hline Melanargia galathea & MELGAL & 42.9 & 47.9 & 3 & oligophagous & - & \\
\hline Aglais urticae & AGLURT & 38.1 & 35.3 & 6 & monophagous & - & \\
\hline Neptis rivularis & NEPRIV & 33.3 & 22.7 & 3 & oligophagous & $\mathrm{LC}$ & priority protected \\
\hline Issoria lathonia & ISSLAT & 23.8 & 30.5 & 5 & monophagous & - & \\
\hline Polyommatus icarus & POLICA & 23.8 & 62.0 & 4 & oligophagous & - & \\
\hline Coenonympha spp. & COESPP & 19.0 & 17.9 & 3 & polyphagous & - & \\
\hline
\end{tabular}

plant specialization (Settele et al. 2000 with own additions); Red list status: VU - vulnerable, LC - least concern, "-" not threatened in Vienna (Höttinger et al. 2013). VCR - Vienna Conservation Regulation 2000 (Wiener Naturschutzverordnung 2000) 

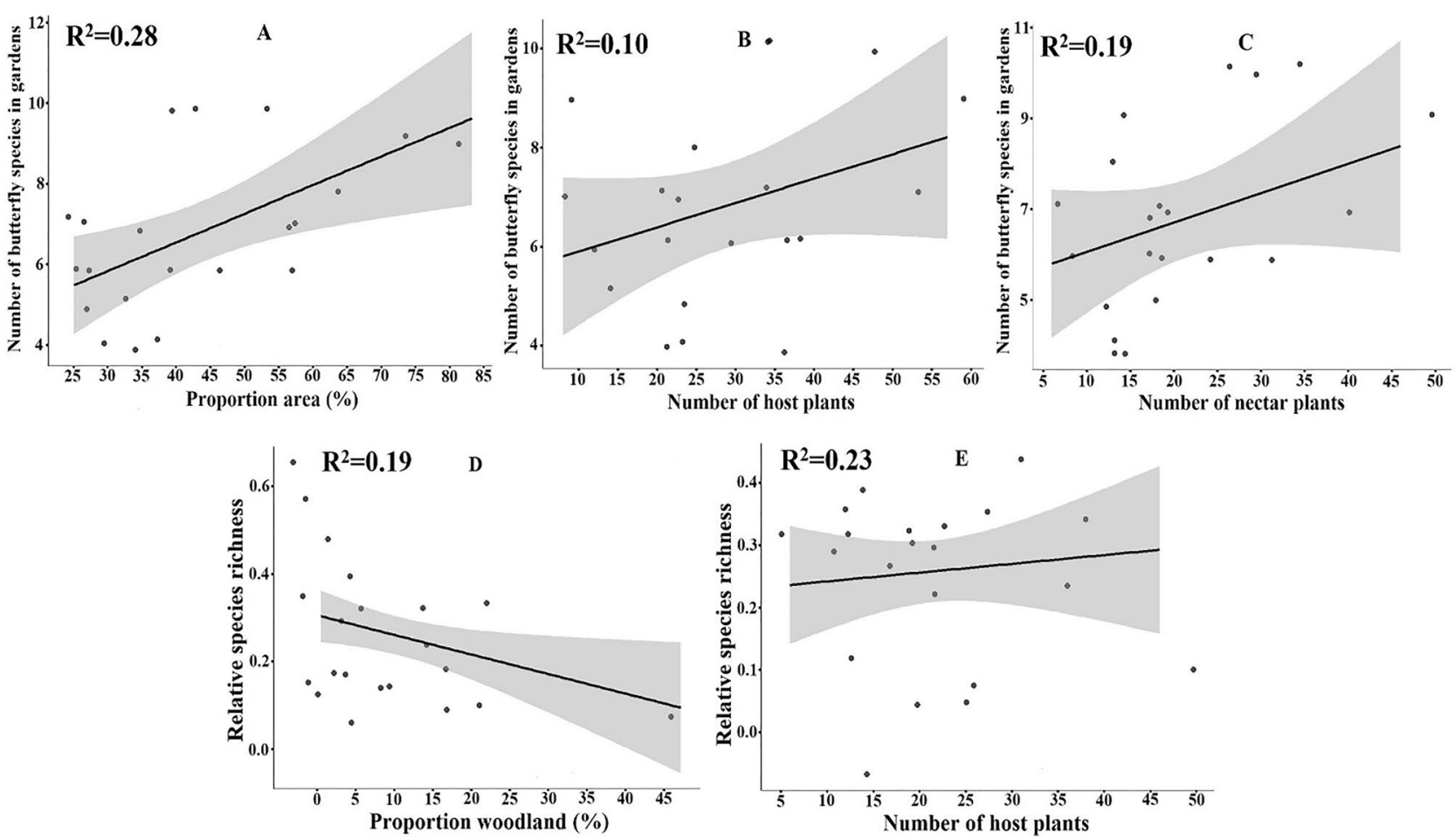

Fig. 2 Linear regression showing the relationship between the number of butterfly species and (A) Proportion area relevant for butterflies in the garden $(\%),(\mathbf{B})$ the number of host plant species in the garden,

populations. Butterflies spend a substantial part of their time feeding and searching for nectar sources (Dennis et al. 2006; Thomas et al. 2011). Thus, a private garden designated for butterfly promotion should host a high diversity of nectar plant species (Curtis et al. 2015). In fact, in urban landscapes, where even the natural or semi-natural habitats have poor nectar resources (Hicks et al. 2016), private gardens represent the main patches of suitable habitat for flowerdependent arthropods, especially pollinators like butterflies (Muratet and Fontaine 2015). In this context, private gardens with enhanced nectar plant communities in highly urbanized areas are likely to be beneficial for butterflies.

Literature for the broader public that aims at promoting gardening for butterflies focuses strongly on the flower needs and only marginally considers relations with the surrounding landscape (Witt 2001). Although gardeners clearly cannot influence the latter, butterfly promotion should not be limited to planting Buddleja bushes; other plants are equivalent or even better. In a detailed survey (Straka 2010), 12 of the 24 recorded butterfly species were observed on Buddleja, but only $10.4 \%$ of the individuals fed on Buddleja. In total, butterflies utilized 114 nectar plant species. In a private garden near Vienna, Straka (2010) recorded 9 out of 30 butterfly species and 53 of the 627 individuals (8.5\%) on Buddleja. This suggests that Buddleja can help to increase species
(C) number of nectar plant species in the garden; (D) relative species richness compared to woodland and (E) number of host plant species in the garden

numbers in Viennese private gardens, however based on our results, increasing numbers of host plant and a broader representation of different nectar plants species must be recommended in the private gardens.

Similarity of species richness between private gardens and the surrounding landscape indicates that the private garden assemblages depend on an exchange with butterfly populations from the surroundings. This finding may not be surprising because many of the species recorded in the studied private gardens were generalists and very mobile (Matteson and Langellotto 2010). Consequently, the more species-rich the landscape species pool, the more species can potentially appear in a private garden. The relationship between butterfly species diversity in private gardens and surrounding habitat types indicates that habitat diversity in the surroundings could increase butterfly diversity in the private gardens (Mukherjee et al. 2018). Surprisingly, the proportion of grassland and other open habitats in the surroundings was not an important variable, although species of these habitats made up a high share of the observed species set. One explanation is that the land-use data were too coarse and failed to cover many very small patches of open landscape that still serve as butterfly habitats (Lizée et al. 2012), or that the plant species composition in the grassland could not provide enough food resources to butterflies due 
Fig. 3 Correlation matrix showing co-occurrences of species abundance, richness and landscape characteristics. Negative correlations are shown in red color and positive correlations are presented in blue. The size of the circle and color intensity is relative to the correlation coefficients. In the right side of the matrix, the legend color shows the corresponding colors and the correlation coefficients

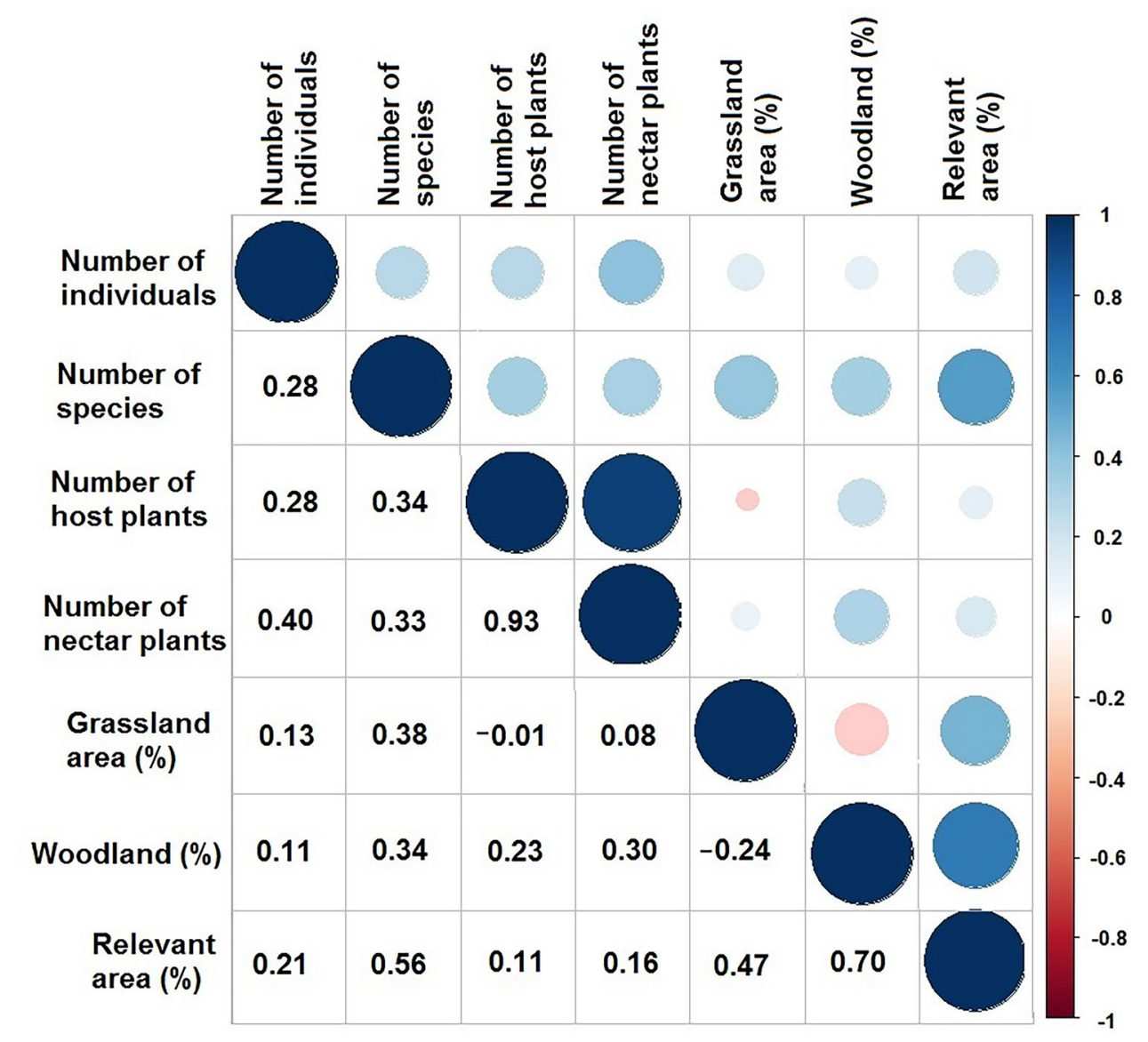

to intensive mowing (Aguilera et al. 2019). Accordingly, a lower percentage of species from the landscape species pool was observed in private gardens with a higher proportion of wooded habitats in their surroundings. Our interpretation is that landscape species pools in more heavily wooded areas comprised woodland species that are unlikely to migrate into private garden areas.

By necessity, simpler observation designs are used for citizen science approaches than in professional monitoring schemes (Engel and Voshell 2002), requiring careful handling of data. Nonetheless, butterfly citizen science approaches can make a valuable contribution to long-term biodiversity monitoring. Furthermore, involving the local public in butterfly monitoring schemes may enhance civic engagement and activity (Leach et al. 2005), especially in programs like "Assessing Butterflies in Europe" (Roy et al. 2020), thus bearing the potential to raise public awareness (Silvertown 2009), e.g. for the loss of biodiversity. Such awareness can, for example, influence gardening practices - such as increased provision of nectar resources for insects - and stimulate an interest in host plant or butterfly observation, which can directly benefit butterfly biodiversity in urban landscapes. Given the increasing popularity of citizen science in the field of biodiversity conservation, this approach has the capacity to strengthen nature-public connectivity in the urban landscape.

Private gardens contribute to conservation efforts for butterflies in Vienna mainly by providing nectar and host plant species. The close association of the introduced bush Spiraea sp. with the populations of Neptis rivularis in the suburban and urban area of Vienna (Räuschl 2002) demonstrates that protected species can profit even from ornamental plants in private gardens and parks. Such associations should be considered in any private and public planning process. To encourage people to take up wildlife gardening, particularly butterfly gardening, we suggest generating and implementing a Garden Habitat Action Plan (Ryall and Hatherell 2003). This would help establish private gardens as important stepping stones and habitats for butterflies and many other species in urban landscapes (Garbuzov and Ratnieks 2014). Furthermore, citizen-science based research is an important way to help foster the human-nature-relationship, one place to do this kind of research is private gardens, it helps raise awareness about urban gardens as refuges while allowing the study of nature in private gardens.

Citizen science-based observation of butterflies and gardening with the aim to support butterflies are important keystones in the human-nature-relationship (Snep et al. 2011). 
Gardeners consider their private gardens as a place of reunion with nature (Goddard et al. 2013). Private gardens could provide an ideal link between biological and social sciences, between biodiversity and urban citizens. This in turn would raise awareness for the role of private gardens as biodiversity refuges for butterflies in urban areas. Last but not least, a citizen science approach could provide a great way to study private gardens, which are difficult to sample otherwise at a large scale because of access restrictions.

\section{Conclusions}

This study showed that the diversity of butterflies observed in private gardens was influenced by the composition of the surrounding landscape, the butterfly diversity in the surrounding landscape, and the diversity of nectar and host plants in the private gardens. Private gardens in Vienna support common butterfly species mostly by providing nectar and host plants. Although private gardens are currently not crucial for conserving rare and endangered species, their role for species that are still common is important because even those species can show negative population trends (Dennis et al. 2017). A citizen science approach - like the one presented here - can be useful to monitor population trends of common butterfly species and to to promote public awareness of butterfly conservation issues.

Acknowledgements We would like to thank all private garden owners, Martin Wiemers and Ulrich Straka for comments on the manuscript, and Klaus Kramer and Andreas Kasper from the Municipal Government of Vienna for providing GIS data and the overview map of Vienna.

Author contributions Study design: TF and TD. Field collections: MP. Data analysis: RIH and TD. Scientific writing: RIH, MP and DM. Scientific review: TF and DM. All authors read and approved the final manuscript.

Funding Open access funding provided by University of Natural Resources and Life Sciences Vienna (BOKU). The author(s) received no financial support for the research, authorship, and/or publication of this article.

Availability of data Data will be available on request.

\section{Declarations}

Ethics approval Not applicable.

Consent to participate Not applicable.

Consent for publication All authors consent to the publication of this work.
Conflicts of interest/competing interests All authors have agreed with the manuscript contents, declare no conflict of interest and approved the final version.

Open Access This article is licensed under a Creative Commons Attribution 4.0 International License, which permits use, sharing, adaptation, distribution and reproduction in any medium or format, as long as you give appropriate credit to the original author(s) and the source, provide a link to the Creative Commons licence, and indicate if changes were made. The images or other third party material in this article are included in the article's Creative Commons licence, unless indicated otherwise in a credit line to the material. If material is not included in the article's Creative Commons licence and your intended use is not permitted by statutory regulation or exceeds the permitted use, you will need to obtain permission directly from the copyright holder. To view a copy of this licence, visit http://creativecommons.org/licenses/by/4.0/.

\section{References}

Aguilera G, Ekroos J, Persson AS, Pettersson LB, Öckinger E (2019) Intensive management reduces butterfly diversity over time in urban green spaces. Urban Ecosyst 22:335-344

Baker AM, Potter DA (2019) Configuration and location of small urban gardens affect colonization by monarch butterflies. Front Ecol Evol 7:474

Baldock KC, Goddard MA, Hicks DM, Kunin WE, Mitschunas N, Morse H, Osgathorpe LM, Potts SG, Robertson KM, Scott AV, Staniczenko PP (2019) A systems approach reveals urban pollinator hotspots and conservation opportunities. Nat Ecol Evol 3:363-373

Bergerot B, Merckx T, Van Dyck H, Baguette M (2012) Habitat fragmentation impacts mobility in a common and widespread woodland butterfly: do sexes respond differently? BMC Eco 12:1-11

Bergman KO, Dániel-Ferreira J, Milberg P, Öckinger E, Westerberg L (2018) Butterflies in Swedish grasslands benefit from forest and respond to landscape composition at different spatial scales. Landsc Ecol 33:2189-2204

Bivand R, Lewin-Koh N, Pebesma E, Archer E, Baddeley A, Bearman N, Bibiko HJ, Brey S, Callahan J, Carrillo G (2019) maptools: Tools for handling spatial objects. $\mathrm{R}$ package version $0.9,5$

Carlucci M, Ferrara C, Rontos K, Zambon I, Salvati L (2020) The long breadth of cities: revisiting worldwide urbanization patterns, 1950-2030. Appl Econ 52:4162-4174

Central Institute for Meteorology and Geodynamics (2016) Zentralanstalt für Meteorologie und Geodynamik. https://www.zamg. ac.at/cms/en/. Accessed 12 May 2016

City of Vienna (2016) Stadt Wien. https://open.wien.gv.at/site/. Accessed 11 Apr 2016

Corcos D, Cerretti P, Caruso V, Mei M, Falco M, Marini L (2019) Impact of urbanization on predator and parasitoid insects at multiple spatial scales. PLoS One 14:e0214068

Cubino JP, Cavender-Bares J, Groffman PM, Avolio ML, Bratt AR, Hall SJ, Larson KL, Lerman SB, Narango DL, Neill C, Trammell TL (2020) Taxonomic, phylogenetic, and functional composition and homogenization of residential yard vegetation with contrasting management. Landsc Urban Plan 202:103877

Curtis RJ, Brereton TM, Dennis RL, Carbone C, Isaac NJ (2015) Butterfly abundance is determined by food availability and is mediated by species traits. J Appl Ecol 52:1676-1684

Dennis RL, Shreeve TG, Van Dyck H (2006) Habitats and resources: the need for a resource-based definition to conserve butterflies. Biodivers Conserv 15:1943-1966

Dennis EB, Morgan BJT, Roy DB, Brereton TM (2017) Urban indicators for UK butterflies. Ecol Indicat 76:184-193 
Dover J, Settele J (2009) The influences of landscape structure on butterfly distribution and movement: a review. J Insect Conserv 13:3-27

Dylewski Ł, Maćkowiak Ł, Banaszak-Cibicka W (2019) Are all urban green spaces a favourable habitat for pollinator communities? Bees, butterflies and hoverflies in different urban green areas. Ecol Entomol 44:678-689

Engel SR, Voshell JR (2002) Volunteer biological monitoring: can it accurately assess the ecological condition of streams? Am Entomol 48:164-177

Fontaine B, Bergerot B, Le Viol I, Julliard R (2016) Impact of urbanization and gardening practices on common butterfly communities in France. Ecol Evol 6:8174-8180

Freitas ÉVD, das Dores Magalhães Veloso M, de Araújo WS (2020) Urbanization alters the composition, but not the diversity and structure, of Neotropical savanna woody plant communities. Folia Geobot 55:95-108

Garbuzov M, Ratnieks FLW (2014) Quantifying variation among garden plants in attractiveness to bees and other flower-visting insects. Funct Ecol 28:364-374

Goddard MA, Dougill AJ, Benton TG (2013) Why garden for wildlife? Social and ecological drivers, motivations and barriers for biodiversity management in residential landscapes. Ecol Econ 86:258-273

Hallmann CA, Sorg M, Jongejans E, Siepel H, Hofland N, Schwan H, Stenmans W, Müller A, Sumser H, Hörren T, Goulson D (2017) More than 75 percent decline over 27 years in total flying insect biomass in protected areas. PLoS One 12:e0185809

Han D, Zhang C, Wang C, She J, Sun Z, Zhao D, Bian Q, Han W, Yin L, Sun R, Wang X (2021) Differences in Response of Butterfly Diversity and Species Composition in Urban Parks to Land Cover and Local Habitat Variables. Forests 12:140

Harrison XA (2014) Using observation-level random effects to model overdispersion in count data in ecology and evolution. Peer $\mathbf{J}$ 2:e616

Hicks DM, Ouvrard P, Baldock KC, Baude M, Goddard MA, Kunin WE, Mitschunas N, Memmott J, Morse H, Nikolitsi M, Osgathorpe LM (2016) Food for pollinators: quantifying the nectar and pollen resources of urban flower meadows. PLoS One 11:e0158117

Höttinger H, Pennerstorfer J, Pendl M, Wiemers M, Räuschl G (2006) Verbreitungskarten der Tagschmetterlinge der Stadt Wien (Lepidoptera: Papilionoidea \& Hesperioidea). Beitr Entomofaunistik 7:69-104

Höttinger H, Pendl M, Wiemers M, Pospisil A (2013) Insekten in Wien - Tagfalter. In: Zettel H, Gaal-Haszler S, Rabitsch W, Christian E (eds). Insekten in Wien. Österreichische Gesellschaft für Entomofaunistik, Wien

Hussain RI, Brandl M, Maas B, Rabl D, Walcher R, Krautzer B, Entling MH, Moser D, Frank T (2021) Re-established grasslands on farmland promote pollinators more than predators. Agric Ecosyst Environ 319:107543

Jain A, Chan SKM, Vlasanek P, Webb EL (2020) Impacts of habitat on butterfly dispersal in tropical forests, parks and grassland patches embedded in an urban landscape. Biotropica 52:404-409

Kühn E, Feldmann R, Harpke A, Hirneisen N, Musche M, Leopold P, Settele J (2008) Getting the public involved in butterfly conservation: lessons learned from a new monitoring scheme in Germany. Isr J Ecol Evol 54:89-103

Kuussaari M, Toivonen M, Heliölä J, Pöyry J, Mellado J, Ekroos J, Hyyryläinen V, Vähä-Piikkiö I, Tiainen J (2021) Butterfly species' responses to urbanization: differing effects of human population density and built-up area. Urban Ecosyst 24:515-527

Leach M, Scoones I, Wynne B (2005) Science and citizens: Globalization and the challenge of engagement (Vol. 2). Zed Books
Lee CM, Park JW, Kwon TS, Kim SS, Ryu JW, Jung SJ, Lee SK (2015) Diversity and density of butterfly communities in urban green areas: an analytical approach using GIS. Zool Stud 54:4

Lerman SB, Contosta AR, Milam J, Bang C (2018) To mow or to mow less: Lawn mowing frequency affects bee abundance and diversity in suburban yards. Biol Conserv 221:160-174

Lewandowski E, Oberhauser K (2016) Butterfly citizen science projects support conservation activities among their volunteers. Citiz Sci Theory Pr 1:1-8

Liu Z, He C, Wu J (2016) The relationship between habitat loss and fragmentation during urbanization: an empirical evaluation from 16 world cities. PLoS One 11:e0154613

Liivamägi A, Kuusemets V, Kaart T, Luig J, Diaz-Forero I (2014) Influence of habitat and landscape on butterfly diversity of seminatural meadows within forest-dominated landscapes. J Insect Conserv 18:1137-1145

Lizée MH, Bonardo R, Mauffrey JF, Bertaudière-Montes V, Tatoni T, Deschamps-Cottin M (2011) Relative importance of habitat and landscape scales on butterfly communities of urbanizing areas. C R Biol 334:74-84

Lizée MH, Manel S, Mauffrey JF, Tatoni T, Deschamps-Cottin M (2012) Matrix configuration and patch isolation influences override the species-area relationship for urban butterfly communities. Landsc Ecol 27:159-169

Loos J, Horcea-Milcu AI, Kirkland P, Hartel T, Osváth-Ferencz M, Fischer J (2015) Challenges for biodiversity monitoring using citizen science in transitioning social-ecological systems. J Nat Conserv 26:45-48

MacIvor SJ, Lundholm J (2011) Insect species composition and diversity on intensive green roofs and adjacent level-ground habitats. Urban Ecosyst 14:225-241

Majewska AA, Sims S, Wenger SJ, Davis AK, Altizer S (2018) Do characteristics of pollinator-friendly gardens predict the diversity, abundance, and reproduction of butterflies? Insect Conserv Divers $11: 370-382$

Matteson KC, Langellotto GA (2010) Determinates of inner city butterfly and bee species richness. Urban Ecosyst 13:333-347

Muratet A, Fontaine B (2015) Contrasting impacts of pesticides on butterflies and bumblebees in private gardens in France. Biol Conserv 182:148-154

Mukherjee S, Banerjee S, Basu P, Saha GK, Aditya G (2018) Butterflyplant network in urban landscape: Implication for conservation and urban greening. Acta Oecol 92:16-25

O'Connell M, Jordan Z, McGilvray E, Cohen H, Liere H, Lin BB, Philpott SM, Jha S (2021) Reap what you sow: local plant composition mediates bumblebee foraging patterns within urban garden landscapes. Urban Ecosyst 24:391-404

Öckinger E, Dannestam Å, Smith HG (2009) The importance of fragmentation and habitat quality of urban grasslands for butterfly diversity. Landsc Urban Plan 93:31-37

Piano E, Souffreau C, Merckx T, Baardsen LF, Backeljau T, Bonte D, Brans KI, Cours M, Dahirel M, Debortoli N, Decaestecker E (2020) Urbanization drives cross-taxon declines in abundance and diversity at multiple spatial scales. Glob Change Biol 26:1196-1211

Pickett ST, Cadenasso ML, Grove JM, Boone CG, Groffman PM, Irwin E, Kaushal SS, Marshall V, McGrath BP, Nilon CH, Pouyat RV (2011) Urban ecological systems: Scientific foundations and a decade of progress. J Environ Manage 92:331-362

Pocock MJ, Tweddle JC, Savage J, Robinson LD, Roy HE (2017) The diversity and evolution of ecological and environmental citizen science. PLoS One 12:e172579

Pollard E, Yates TJ (1993) Monitoring butterflies for ecology and conservation. The British Butterfly Monitoring Scheme. Chapman and Hall, London 
Räuschl G (2002) Zu Ökologie und Artenschutz des Schwarzen Trauerfalters (Neptis rivularis). Beitr Entomofaunistik 3:81-85

Roy DB, Bourn N, Collins S, Dennis EB, Schmucki R, Settele J, Sevilleja CG, Van Swaay CAM, Wynhoff I (2020) Assessing Butterflies in Europe: executive summary. Butterfly Conservation Europe

Ryall C, Hatherell P (2003) A survey of strategies adopted by UK Wildlife Trusts in the promotion of gardening for wildlife. Environmentalist 23:81-87

Sanderson EW, Huron A (2011) Conservation in the city. Conserv Biol 25:421-423

Schneider C, Dover J, Fry GL (2003) Movement of two grassland butterflies in the same habitat network: the role of adult resources and size of the study area. Ecol Entomol 28:219-227

Settele J, Feldmann R, Reinhardt R (2000) Die Tagfalter Deutschlands. Ulmer, Stuttgart

Silvertown J (2009) A new dawn for citizen science. Trends Ecol Evol 24:467-471

Snep R, WallisDeVries M, Opdam P (2011) Conservation where people work: A role for business districts and industrial areas in enhancing endangered butterfly populations? Landsc Urban Plan 103:94-101

Steffan-Dewenter I, Tscharntke T (2000) Butterfly community structure in fragmented habitats. Ecol Lett 3:449-456
Straka U (2004) Stadtgärten als Lebensraum für Tagfalter: Beobachtungen in einem Garten in Stockerau (Niederösterreich) in den Jahren 1999-2003. Beitr Entomofaunistik 5:67-78

Straka U (2010) Tagfalter in Stadtgärten: Beobachtungen von Tagfaltern im Garten der Universität für Bodenkultur (BOKU) Wien in den Jahren 2006-2010. Verh Zool-Bot Ges 147:31-49

Strausz M, Fiedler K, Franzén M, Wiemers M (2012) Habitat and host plant use of the Large Copper Butterfly Lycaena dispar in an urban environment. J Insect Conserv 16:709-721

Thomas JA, Simcox DJ, Hovestadt T (2011) Evidence based conservation of butterflies. J Insect Conserv 15:241-258

Vickery M (2007) Gardens as an aid to the conservation of butterflies. Sci Prog 90:223-244

Warren MS, Maes D, van Swaay CA, Goffart P, Van Dyck H, Bourn NA, Wynhoff I, Hoare D, Ellis S (2021) The decline of butterflies in Europe: Problems, significance, and possible solutions. Proc Natl Acad Sci 118:e2002551117

Wiener Naturschutzverordnung (2000) Wr. NschVO, LGB1 vom 08.03.2000. https://www.wien.gv.at/recht/landesrecht-wien/recht svorschriften/html/14800200.htm. Accessed 26 Jun 2016

Witt R (2001) Ein Garten für Schmetterlinge. Kosmos, Stuttgart

Woodward J, Eyre M, Luff M (2003) Beetles (Coleoptera) on brownfield sites in England: an important conservation resource? J Insect Conserv 7:22-231 